\title{
Constitutional International Environmental Law for the Anthropocene?
}

\author{
Louis J. Kotzé and Wendy Muzangaza
}

\section{Correspondence}

Email: 1kotze@lincoln.ac.uk

International environmental law (IEL) seems unable to comprehensively and effectively respond to the Anthropocene's deepening socio-ecological crisis. While there are several reasons for this state of affairs, one in particular relates to the argument that IEL lacks higher order, global constitutional-type norms that could constrain State sovereignty and the free will of States in their relations with the environment. As a contribution to the debate on the effectiveness of IEL in the Anthropocene, we seek here for such higher order constitutional norms in the areas of customary international law and jus cogens. We conduct the ensuing analysis through the lens of the 'normative hierarchy' and 'global constitutionalism' theories of international law and critically reflect on the extent to which these norms could play a meaningful role to mediate the humanenvironment interface in the Anthropocene.

\section{INTRODUCTION}

We are in the midst of one of the most profound, and potentially fatal, existential crises in humanity's relative short existence on Earth. This crisis, which is of our own making, is vividly explicated by the Anthropocene and its imagery. In the Anthropocene, humans as ecological agents have changed and continue to change Earth and its natural system, transforming Earth 'rapidly and irreversibly into a state unknown in human experience'. ${ }^{1}$ As a result of these human-induced impacts, the Earth is moving into a critically unstable state, with the Earth system gradually becoming less predictable, non-stationary and less harmonious as a result of the global human imprint on the biosphere. ${ }^{2}$

On the back of the Anthropocene's imagery, it has further been suggested that humanity has already crossed some, and are fast approaching several other, planetary boundaries. ${ }^{3}$ These planetary boundaries determine the self-regulating capacity of the Earth system, otherwise understood as biophysical thresholds. The boundary theory seeks to refocus attention on the nonnegotiable planetary preconditions that humanity must respect in order to avoid the risk of calamitous Earth system change. As a global environmental change threshold reference framework, planetary boundaries are signalling that humanity is entering a so-called 'unsafe operating space', ${ }^{4}$ which implies a risk of damaging or catastrophic loss of existing ecosystem functions and services across the biosphere. ${ }^{5}$ Of the nine planetary boundaries, ${ }^{6}$ it is estimated that four have already been crossed, i.e. climate change, genetic diversity, land system change and biochemical flows. ${ }^{7}$

\footnotetext{
${ }^{1}$ AD Barnosky et al, 'Approaching a State Shift in Earth's Biosphere' (2012) 486 Nature 52, 52.

${ }^{2}$ LJ Kotzé, 'Rethinking Global Environmental Law and Governance in the Anthropocene' (2014) 32 Journal of Energy and Natural Resources Law 121, 121.

${ }^{3}$ J Rockström et al, 'Planetary Boundaries: Exploring the Safe Operating Space for Humanity' (2009) 14 Ecology and Society 1,1 .

${ }^{4}$ W Steffen et al, 'The Anthropocene: Conceptual and Historical Perspectives' (2011) 369 Philosophical Transactions of the Royal Society 842,860 .

${ }^{5}$ BW Brook et al, 'Does the Terrestrial Biosphere Have Planetary Tipping Points?' (2013) 28 Trends in Ecology and Evolution 396, 396.

${ }^{6}$ These are: climate change, biosphere integrity, land system change, freshwater use, biochemical flows, ocean acidification, atmospheric aerosol loading, stratospheric ozone depletion, and novel entities.

${ }^{7}$ J Rockström et al, 'A Safe Operating Space for Humanity' (2009) 461 Nature 472, 472; and more recently, W Steffen et al, 'Planetary Boundaries: Guiding Human Development on a Changing Planet' (2015) 347 Science 736.
} 
The Anthropocene and its related image of planetary boundaries could have myriad farreaching, but underexplored, epistemological, ontological and normative implications for international environmental law (IEL), which still remains the most comprehensive body of law encapsulating all post-national norms that seek to mediate the human-environment interface. As the world is searching for new paradigms to understand the causes and consequences of, and to design more effective responses to, global socio-ecological decay, the Anthropocene as a trope or analytical framework is steadily opening up hitherto epistemological closures, as it were, thereby allowing us to revisit and re-envision the age-old normative constructs through which we have regulated human behaviour and its impacts on the environment to date. To this end, Stephens correctly points out that "most accounts of international environmental law have yet to come to grips with the immense consequences that the Anthropocene poses for global environmental governance'. 8

What seems clear though is that IEL is generally perceived to be unable to comprehensively and effectively respond to the Anthropocene's global socio-ecological crisis. ${ }^{9}$ Some even opine that this body of law has contributed to causing, and still actively perpetuates, Anthropoceneinducing events that are pushing humanity across planetary boundaries. ${ }^{10}$ IEL is believed, among many other considerations, to grant too much latitude to State sovereignty while ineffectively sanctioning States' non-compliance with their obligations under IEL. ${ }^{11}$ The inefficacy of IEL is supposedly not as a result of a lack of norms:

\section{global environmental conditions have continued to deteriorate despite the accumulating body of international environmental law ... over 700 multilateral environmental agreements (MEAs) have been adopted since 1857. However, during this period, the rate of anthropogenic global environmental change has been accelerating. ${ }^{12}$}

Clearly alternative and more radical ways must be found to address the most pressing areas of concern that impact the effectiveness of IEL if we were to more effectively respond to the multiple existing and growing socio-ecological challenges of the Anthropocene.

One such alternative could lie in the constitutionalism paradigm, which, understood from a domestic perspective, is premised on the idea that certain norms and the obligations they impose cannot give way to other obligations. Elevating environmental protection to a constitutional concern, and more importantly to a constitutional obligation that cannot give way to other obligations, could be an effective strategy to enhance environmental protection by means of law. It has, after all, already been shown that domestic constitutional measures, especially environmental human rights that are hierarchically superior to other norms, have the potential to enhance environmental protection. ${ }^{13}$

While constitutional environmental norms clearly exist in domestic constitutions the world over, it is a far more complex endeavour to determine their existence in the international legal order and to evaluate their potential contribution to global environmental protection. More general efforts to find and interrogate global 'constitutional' norms occur within the paradigms of 'normative hierarchy in international law' and that of 'global constitutionalism'. The part of the

\footnotetext{
${ }^{8}$ T Stephens, 'Reimagining International Environmental Law in the Anthropocene' in LJ Kotzé (ed), Environmental Law and Governance for the Anthropocene (Hart 2017) 31, 32.

9 ibid.

10 See, e.g., A Grear, “"Anthropocene, Capitalocene, Chthulucene”: Re-encountering Environmental Law and its "Subject” with Haraway and New Materialism' in Kotzé (n 8) 77.

${ }^{11}$ LJ Kotzé, ‘Arguing Global Environmental Constitutionalism’ (2012) 1 Transnational Environmental Law $199,202$.

${ }^{12}$ RE Kim and K Bosselmann, 'International Environmental Law in the Anthropocene: Towards a Purposive System of Multilateral Environmental Agreements' (2013) 2 Transnational Environmental Law 285, 285-286.

${ }^{13}$ See, for a comprehensive discussion, J May and E Daly, Global Environmental Constitutionalism (Cambridge University Press 2015); D Boyd, The Environmental Rights Revolution: A Global Study of Constitutions, Human Rights and the Environment (UBC Press 2012).
} 
debate that specifically focuses on the emergence of global environmental constitutional norms has only been emerging recently. ${ }^{14}$ The normative hierarchy theory postulates that certain core norms exist that articulate the fundamental values of the international community and that enjoy a place at the top of international law's normative hierarchy. The debate on normative hierarchy is a central structural component of the global constitutionalism paradigm, ${ }^{15}$ which proposes that, very much like a domestic constitutional setting, hierarchically superior norms exist in a codified or uncodified international constitutional setting which could render some international law norms more superior, comprehensive, durable and enforceable. From a Western liberal constitutionalism point of view, global constitutionalism emphasizes the potential of constitutionalism to achieve a good and/or more effective global law and governance order in that it aims 'to guarantee a political [and socio-juridical] process that brings about sustainable and fair compromises between diverging interests'. ${ }^{16}$ It could do so by restricting arbitrary rule of global powers through a global-type constitution containing a set of higher order norms and in a related sense to 'softening' the sovereignty of States and restricting their unilateral actions through the limits imposed by higher order norms encapsulated in customary international law (CIL) or jus cogens norms, for example. The crux of the global constitutionalism argument is that the higher a norm is located on international law's hierarchy, the stronger it is and the greater potential it has to be observed by States and to be enforced against States, not only in relation to global humanitarian, peace or human rights issues, but increasingly also environmental concerns, where it would then manifest as global environmental constitutionalism. The question we raise in this article is: to what extent are CIL and jus cogens norms recognized as binding higher order global constitutional norms that could contribute to constraining State sovereignty and the free will of States as far as the environment is concerned? The added value in practice of viewing certain environmental norms as being of a global constitutional nature, lies in the consideration that such norms could elevate environmental protection to a superior normative position on par with other (not entirely unrelated) pressing concerns of the international community that are juridically protected, such as safeguarding human dignity and maintaining peace.

To this end, the original contribution of this article lies in its attempt to offer an assessment of the CIL and jus cogens status of a selection of some major IEL norms, with a view to interrogating whether these norms could be said to form part of a global constitutional regime for environmental protection in the Anthropocene. In doing so, the article situates the discussion on normative hierarchy within the context of global environmental constitutionalism and that of the Anthropocene narrative; formulates the broad outlines of the notion of global environmental constitutionalism; and identifies and interrogates a set of higher order global environmental constitutional norms that might form part of a tentatively emerging, yet disaggregated, global environmental constitution for the Anthropocene. The discussion commences by briefly interrogating in Section 2 the normative hierarchy theory and the global environmental constitutionalism paradigm, as well as the interrelationship between these concepts. The article then investigates in Section 3 whether higher order 'constitutional' environmental CIL norms exist which could form part of a global environmental constitutional regime. Part 4 focuses on whether environmental jus cogens norms exist which, being non-derogable or peremptory, would be situated at the apex of IEL's normative hierarchy. In the concluding Section 5 we offer brief views on the potential of constitutional type environmental CIL and jus cogens norms to play a

\footnotetext{
${ }^{14}$ One of the most notable publications on normative hierarchy in the environmental domain is arguably D Shelton, 'Resolving Conflicts between Human Rights and Environmental Protection: Is There a Hierarchy?' in E de Wet and J Vidmar (eds), Hierarchy in International Law: The Place of Human Rights (Oxford University Press 2012). For an in-depth discussion of global environmental constitutionalism, see LJ Kotzé, Global Environmental Constitutionalism in the Anthropocene (Hart 2016).

${ }^{15}$ DJ Rafferty, 'Constitutionalism in International Law: The Limits of Jus Cogens' (LLM dissertation, University of Pretoria 2012) 8.

${ }^{16}$ C Volk, 'Why Global Constitutionalism Does not Live up to Its Promises' (2012) 4 Göttingen Journal of International Law 551, 560.
} 
meaningful role as part of the post-State body of environmental laws that mediate the humanenvironment interface in the Anthropocene.

\section{NORMATIVE HIERARCHY IN THE CONTEXT OF GLOBAL ENVIRONMENTAL CONSTITUTIONALISM}

Domestic legal systems are clearly hierarchical in nature. The vertical hierarchy in these systems is mostly as a result of constitutions and their provisions which are considered apex law that all other laws are subject to. ${ }^{17}$ The same cannot necessarily be said of the system of international law, however, mostly because international law operates mostly horizontally at a different level (postState), between different subjects (States), and it addresses interstate global regulatory concerns as opposed to localized concerns. Most importantly for present purposes, it is unclear whether international law, or some of its aspects and norms, could be described 'constitutional' in any broad sense in the same way one would normatively characterize the legal system of a domestic constitutional State. This is an important consideration because of the fundamental primacy of a constitution in any legal order, which is 'the sum of basic (materially most important) legal norms which comprehensively regulate the social and political life of a polity', ${ }^{18}$ thereby providing the foundation of a legal order, establishing the trias politica of the State and providing the basis and legitimacy for law, politics and legality. ${ }^{19}$ It is also an important consideration in the context of international law to the extent that the notion of constitutionalism could be employed to argue for more effective, universally binding, and higher-order international law norms that bind States regardless of their consent to such norms.

Considering therefore the preeminence of constitutionalism in domestic legal orders and the associated notions of stability and good rule it generally imparts, it seems almost intuitive to also search for traces of constitutionalism in the international legal order. Because constitutional law mostly establishes a normative hierarchy to the extent that it creates binding apex legal norms, it is perhaps no surprise that the constitutionalism debate in international law reflects to a considerable extent on the issue of normative hierarchy. International lawyers have for many years debated the existence, nature and purpose of a normative hierarchy in international law; ${ }^{20}$ a debate which was sparked by the emergence of the concept of jus cogens norms through Article 53 of the Vienna Convention on the Law of Treaties (VCLT). ${ }^{21}$ This discussion predominantly occurs in the context of the global constitutionalism paradigm, which seeks traces of constitutionalism in the corridors of international law. With a view to tracing the main threads of this debate, this part briefly reflects on the notions of global constitutionalism and its specific environment-related manifestation of global environmental constitutionalism. The discussion then focuses on the notion of normative hierarchy with a view to establishing if a hierarchy of norms exists in international

\footnotetext{
${ }^{17}$ H Kelsen, General Theory of Law and State (The Lawbook Exchange Ltd 1945) 115.

${ }^{18}$ A Peters, 'Compensatory Constitutionalism: The Function and Potential of Fundamental International Norms and Structures' (2006) 19 Leiden Journal of International Law 579, 581.

${ }^{19}$ M Loughlin, 'What is Constitutionalisation?' in P Dobner and M Loughlin (eds), The Twilight of Constitutionalism (Oxford University Press 2010) 47, 50.

${ }^{20}$ M Koskenniemi, 'Hierarchy in International Law: A Sketch' (1997) 8 European Journal of International Law 566, 567; E De Wet, 'The Emerging International Constitutional Order: The Implications of Hierarchy in International Law for the Coherence and Legitimacy of International Decision-Making' (2007) 10 Potchefstroom Electronic Law Journal 21, 21; D Shelton, 'Normative Hierarchy in International Law' (2006) 100 American Journal of International Law 291, 291.

21 'A treaty is void if, at the time of its conclusion, it conflicts with a peremptory norm of general international law. For the purposes of the present Convention, a peremptory norm of general international law is a norm accepted and recognized by the international community of States as a whole as a norm from which no derogation is permitted and which can be modified only by a subsequent norm of general international law having the same character'; Vienna Convention on the Law of Treaties (adopted 23 May 1969, entered into force 27 January 1980) 1155 UNTS 331 (VCLT) art 53.
} 
law generally and with a view to illustrating why normative hierarchy is useful from a global environmental constitutional point of view.

\subsection{Global constitutionalism}

Global constitutionalism derives its core meaning from the notion of a constitution or constitutionalism in a domestic context. While no direct transplantation in a notional or normative sense of domestic constitutionalism to the global sphere is possible, at least not in any unqualified way, it is more likely that core domestic constitutional ideas, norms and/or features could be more or less replicated in the global sphere. Because the totality of the State is not absolute any longer, the modernist idea that constitutionalism can and should only manifest in domestic, State-bound terms are gradually giving way to alternative understandings of constitutionalism's potential relevance and application that reaches beyond the State. ${ }^{22}$ The shift between the world order as we knew it and the considerably more complex globalized world of today, has manifold implications for constitutionalism, not least because State-bound constitutional endeavours 'were operational answers to their times and societies and cannot claim eternal truth' ${ }^{23}$ This realization supports the claim that the terms 'constitution' and 'constitutionalism', while historically State-bound, arguably cannot continue to operate only within the exclusive purview of the nation State; they should and are now loosening up in ways that are going beyond the State: ${ }^{24}$ 'an exclusive focus of constitutionalism on the Nation State cannot be maintained. It needs to give way to a graduated approach which views constitutionalism as a process, extending constitutional structures to fora and layers of governance other than nations'. ${ }^{25}$

Efforts that seek constitutionalism in the global regulatory space manifest clearly, and arguably most intuitively, in the arguments of those suggesting that international law and its governance institutions have become, or are becoming, constitutionalized. Commentators belonging to this predominantly European, and mostly German, influenced school of thought, include Peters, Habermas, Fassbender, Simma, Tomuschat, Von Bogdandy and De Wet. ${ }^{26}$ Some general claims around which these commentators fashion their respective visions of global constitutionalism include: ${ }^{27}$ there is a global government organized around the United Nations (UN) and its institutions with the Charter of the UN serving as its formal, constituting global constitution; there is a discernable international community acting as a constituent power; and an international 'Bill of Rights' exists (consisting of the Universal Declaration of Human Rights, the International Covenant on Civil and Political Rights and the International Covenant on Economic, Social and Cultural Rights), which is similar to a domestic bill of rights that contain elevated human rights norms and obligations based on universal values that supersede other 'inferior' norms. ${ }^{28}$

\footnotetext{
${ }^{22}$ N Walker, 'Taking Constitutionalism Beyond the State' (2008) 56 Political Studies 519, 519.

${ }^{23}$ T Cottier and M Hertig, 'The Prospects of $21^{\text {st }}$ Century Constitutionalism' (2003) 7 Max Planck Yearbook of United Nations Law 261, 263.

24 Peters (n 18) 581.

${ }^{25}$ Cottier and Hertig (n 23) 264.

${ }^{26}$ See A Peters, 'Global Constitutionalism in a Nutshell' in K Dicke et al (eds), Weltinnenrecht: Liber Amicorum Jost Delbrück (Walther Schücking Institut für Internationales Recht 2005) 535; J Habermas, The Divided West (Polity 2006); E De Wet, 'The International Constitutional Order' (2006) 55 International and Comparative Law Quarterly 51; B Fassbender, 'The United Nations Charter as the Constitution of the International Community' (1998) 36 Columbia Journal of International Law 529; B Simma, 'From Bilateralism to Community Interest in International Law' (1994) 250 Recueil des Cours 217; C Tomuschat, 'International Law: Ensuring the Survival of Mankind on the Eve of a New Century' in Recueil Des Cours/Collected Courses (Martinus Nijhoff 1999) 9; A Von Bogdandy, 'Constitutionalism in International Law: Comment on a Proposal from Germany' (2006) 47 Harvard International Law Journal 223.

${ }^{27}$ For a broad overview of this approach, see R MacDonald, 'Fundamental Norms in Contemporary International Law' (1988) 25 Canadian Yearbook of International Law 115.

${ }^{28}$ Walker (n 22) 535-536.
} 
Such an approach to global constitutionalism focuses on establishing the autonomy and authority of international law vis-à-vis State sovereignty and State consent. ${ }^{29}$ At a more practical level it is also about establishing international legal unity as a response to law and governance fragmentation, and perhaps more deliberately, albeit less likely, a global legal integration of States and the creation of a fully representative and comprehensive body of international law. ${ }^{30}$ This approach further describes a global constitutional phenomenon both in terms of formal structure (allocation of competencies and the delineation of spheres of jurisdiction in the international community) and substance (the existence of higher-order norms that must be respected because as apex norms they are considered constitutional). ${ }^{31}$ Especially in terms of the 'new' substance of law that this approach foresees, international law, and by implication global governance, 'can no longer be understood as a neutral, value-free inter-State order, a mere emanation of State interest' ${ }^{32}$ Through global constitutionalism, material constraints are instead placed on State consent and State actions through universally binding apex norms while sovereign interests that run counter to the higher order substance of international law are diluted to some extent through these 'constitutionally' binding norms of international law.

\subsection{Global environmental constitutionalism}

At the domestic level, the reach and relevance of constitutionalism has been extended into the environmental law and governance domain; a process which at once also invites environmentalism into the constitutionalism domain. This is occurring on the back of growing recognition of the need for constitutional norms, institutions, structures and processes to embrace environmental care. Whereas some have called for 'a wider range of options [and] a new paradigm' 33 in this respect, others suggest that in addition to legitimacy, constitutional review, democracy, accountable government and respect for human rights, 'the constitutionalism of the future' must as a result of contemporary threats and challenges such as climate change, embrace notions of human solidarity for the preservation of the planet and its resources and equitable principles in the allocation of scarce resources within countries and between people. ${ }^{34}$

While there is now an abundance of environmental provisions in constitutions the world over, there is still no generally endorsed definition of the concept 'environmental constitutionalism' as it manifests domestically. The main reason is arguably because it has only recently emerged conceptually:

Environmental constitutionalism is a relatively recent phenomenon at the confluence of constitutional law, international law, human rights and environmental law. It embodies the recognition that the environment is a proper subject for protection in constitutional texts and for vindication by constitutional courts worldwide. ${ }^{35}$

One approach to explaining environmental constitutionalism is to distinguish its evaluative, formal or descriptive functions, from its (arguably more important) functional,

\footnotetext{
${ }^{29}$ T Kleinlein, 'Alfred Verdross as a Founding Father of International Constitutionalism?' (2012) 4 Göttingen Journal of International Law 385, 388.

${ }^{30}$ K Milewicz, 'Emerging Patterns of Global Constitutionalization: Toward a Conceptual Framework' (2009) 16 Indiana Journal of Global Legal Studies 413, 424.

${ }^{31}$ Kleinlein (n 29) 391-392.

32 ibid 399.

${ }^{33}$ B Gareau, 'Global Environmental Constitutionalism' (2013) 40 Boston College Environmental Affairs Law Review 403, 408.

${ }^{34} \mathrm{~B}$ Ramcharan, 'Constitutionalism in an Age of Globalisation and Global Threats' in M Frishman and S Muller (eds), The Dynamics of Constitutionalism in the Age of Globalisation (Hague Academic Press 2010) 15, 18-19.

${ }^{35}$ May and Daly (n 13) 1.
} 
prescriptive or substantively constitutional functions. ${ }^{36}$ Whereas formal environmental constitutionalism relates to constitutional law establishing, defining and organizing the main organs of government, its functions and its powers, including of course the powers of environmental authorities, substantive environmental constitutionalism relates to constitutional environmental provisions being substantively constitutional, i.e. superior constitutional environmental provisions that are justiciable, entrenched and that express a common ideology such as through environmental rights. To this end, environmental constitutionalism denotes a regulatory paradigm that seeks to enhance environmental protection by elevating it as a constitutional concern alongside other pertinent (and often related) regulatory issues such as protection of human dignity and freedoms, poverty alleviation and broader human rights protection. Environmental constitutionalism in a procedural and substantive sense, therefore establishes State environmental authorities that must execute environmental law and governance, while at once creating binding apex constitutional norms, such as environmental rights, aimed at environmental protection. ${ }^{37}$

With scholars commencing to explore what constitutional environmental protection could mean in post-State terms, global constitutionalism has only recently been situated in the environmental law and governance domain. That it is critical to instigate such an exploratory exercise is evident from Bosselmann's view that:

we can think of the environment as a universal concern. Arguably, the environment is even more fundamental than human rights as it represents the natural conditions of all life including human beings. Both the protection of human rights and the protection of the environment are constitutionally relevant precisely because of their fundamental importance .... If we accept that the twenty-first century will be defined by its success or failure of protecting human rights and the environment, then global environmental constitutionalism, like global constitutionalism in general, becomes a matter of great urgency. ${ }^{38}$

While domestic environmental constitutionalism is a familiar paradigm that could provide a blueprint for global environmental constitutionalism, global environmental constitutionalism could enable the State to extend its environmental governance functions to the global regulatory space beyond its borders and sphere of direct influence and control, to a space where its abilities and influence are far more tentative, but no less important. To this end, one of the many reasons for pursuing the global constitutionalism agenda and transposing domestic conceptions of constitutionalism globally to the environmental context is to enable States to benefit from the advantages of environmental constitutionalism as a response to the socio-ecological challenges that arise in the Anthropocene. These advantages include that global environmental constitutionalism could: provide higher-order juridical guarantees and care in IEL; fundamentally shape and determine environmental law regimes such as those in MEAs, including the level of environmental care they espouse; foster greater global coordination and cooperation between likeminded actors in global environmental law and governance that aspire to promote and respect commonly agreed upon core environmental values; guarantee longer lasting environmental protection that transcends political short-termism; increase environmental awareness and social involvement; and level the playing field by affording environmental considerations the same, if not greater, status than pure economic developmental concerns in global law, politics and governance. ${ }^{39}$ It is precisely in this context that the practical value of global environmental constitutionalism becomes evident.

\footnotetext{
${ }^{36}$ LJ Kotzé, Global Environmental Constitutionalism in the Anthropocene' in Kotzé (n 8) 205.

${ }^{37}$ LJ Kotzé, 'The Conceptual Contours of Environmental Constitutionalism' (2015) 21 Widener Law Review 187.

${ }^{38}$ K Bosselmann, 'Global Environmental Constitutionalism: Mapping the Terrain' (2015) 21 Widener Law Review $171,173$.

${ }^{39}$ See further Kotzé (n 36).
} 
Most importantly for our present purposes, substantive global environmental constitutionalism seeks, among others, for normatively higher-order environmental protection norms in IEL, in very much the same way that environmental human rights are entrenched in domestic constitutions as apex legal norms. To this end, substantive global environmental constitutionalism attempts to serve as a reform measure to the current global environmental law and governance regime to limit State sovereignty and discourage States' non-compliance with their environmental obligations through norms that are binding on States despite their lack of consent or even in the face of States' deliberate transgressions of binding IEL. Given their universally binding character that does not depend on State consent, the two most likely type of norms to fulfil this role are CIL and jus cogens. The following section explores the dimensions and meaning of the concept 'normative hierarchy', which provides the context for a deeper analysis in the remainder of this article of those norms that are situated at the top of IEL's normative hierarchy.

\subsection{Normative hierarchy}

In general terms, normative hierarchy refers to the relationship between and ordering of legal norms according to their superiority in terms of their objectives, importance of their content, as well as the universal acceptance of their superiority. ${ }^{40}$ Normative hierarchy thus posits the existence of a set of orderly, coherently organized norms, and that it is possible to establish from their position in the hierarchy whether they are superior or inferior norms in law. ${ }^{41}$ It should be reasonably easy to determine such a hierarchy in vertically operative domestic legal systems, which are generally accepted as being hierarchical in nature, ${ }^{42}$ especially because a constitution usually provides superior norms that prevail over all other (statutory and other) norms. In addition, there is often a hierarchy within constitutions themselves, with human rights as apex norms. ${ }^{43}$

Could such a hierarchical setting also exist in the horizontally oriented international legal system $?^{44}$ While there is no consensus on the nature and form of a normative hierarchy in international law, it could be argued that any determination of such a hierarchy must contemplate at least three considerations. First, a norm acquires hierarchical superiority because of its value. ${ }^{45}$ This was confirmed by the International Court of Justice (ICJ) in the Barcelona Traction ${ }^{46}$ case $^{2}$ when it used the words 'importance of the rights involved' in addressing obligations erga omnes. ${ }^{47}$ It is argued that 'value' in this context relates to the worth that a certain norm adds to individual human welfare, ${ }^{48}$ which might explain why human rights are often considered apex norms, also in international law.

Second, it can be argued that the function of a norm also determines its hierarchical superiority. ${ }^{49}$ Norms that are non-derogable and serve to limit State sovereignty are therefore

\footnotetext{
${ }^{40}$ M Petsche, 'Jus Cogens as a Vision of the International Legal Order' (2010) 29 Penn State International Law Review 233, 261; International Law Commission (ILC), 'Fragmentation of International Law: Difficulties Arising from the Diversification and Expansion of International Law, Report of the Study Group of the International Law Commission on its 58th ${ }^{\text {h }}$ session' UN Doc A/CN.4/L.682 (13 April 2006).

${ }^{41}$ JN Mayua, 'Human Rights and Jus Cogens: Questioning the Use of Normative Hierarchy Theory in Human Rights Law’ (LLM dissertation, University of Cape Town 2009) 3.

${ }^{42}$ Kelsen (n 17).

${ }^{43}$ De Wet (n 26) 58; E De Wet and J Vidmar (eds), Hierarchy in International Law: The Place of Human Rights (Oxford University Press 2012) 2.

${ }^{44}$ A question that is specifically being asked in the context of human rights. See, T Meron, 'On a Hierarchy of International Human Rights' (1986) 8 American Journal of International Law 1, 3.

${ }^{45}$ Mayua (n 41) 40.

${ }^{46}$ Case Concerning the Barcelona Traction, Light and Power Company Limited (Belgium v Spain) (Judgment) [1970] ICJ Rep 3 (Barcelona Traction).

47 'Obligations erga omnes' refers to obligations that are owed to the international community of States as a whole and in the protection of which all States have an interest.

${ }^{48}$ Mayua (n 41) 40.

49 ibid.
} 
usually considered to be superior to other 'lesser' norms simply because they have the paramount importance of trying to protect the most basic universal values (such as life and human dignity). ${ }^{50}$ In this sense, it is argued that hierarchical norms appear as a 'result of accommodating competing values' ${ }^{51}$ while at once affording some fundamental norms greater superiority than others.

The third feature of a normative hierarchy in international law is that hierarchically superior norms are seen to be based on the interests of the international community as a whole. ${ }^{52}$ The international community of States can be defined as a collective which has the ability to "frame and direct political power in light of common values and a common good'. ${ }^{33}$ The primary subjects of the international community are States and their representative international organizations with legal personality, which are central to international law making, law enforcement and global governance. ${ }^{54}$ It is argued that the concept of international community entails imposing global public policy on all States, including non-consenting States, to limit their freedom of action where this is necessary to promote the common good of everyone. ${ }^{55}$ This could be done through apex norms of international law, such as those embodied in the so-called International Bill of Rights (referred to above) that reflect the international value system, ${ }^{56}$ that have a strong ethical underpinning and which States are required to incorporate into their domestic systems. ${ }^{57}$ This value system entails the fundamental rules that States have high regard for and that protect, for example, the rights to life and human dignity. ${ }^{58}$

In sum, a normative hierarchy in international law can be argued to mean the systematic ordering of legal norms according to their importance. Such importance depends on the values of the international community, the function of the norms, and their recognition by the international community as superior norms, with some higher-order 'constitutional' and binding norms taking precedence over ordinary or lesser non-binding norms. Although there is general agreement that a normative hierarchy exists in international law, the form, function and nature of such a hierarchy are not always clear:

Public international law, although mostly composed of co-equal norms, shows some elements of hierarchy. At the top of this hierarchy, norms of ius cogens and obligations erga omnes are of a higher legal quality than the mass of ordinary norms. At its bottom, in the grey area between international 'hard law' and 'soft law', are an ever-growing number of amorphous 'concepts' and 'principles', whose nature and normative quality are far from clear. ${ }^{59}$

Several considerations point to the existence of such a hierarchy. First, Article 38 of the Statute of the International Court of Justice (ICJ Statute) suggests that the sources of international law are not on equal normative footing. ${ }^{60}$ The ICJ Statute, for example, refers to judicial decisions

\footnotetext{
${ }^{50} \mathrm{~T}$ Koji, 'Emerging Hierarchy in International Human Rights and Beyond: From the Perspective of Non-Derogable Rights' (2001) 12 European Journal of International Law 917, 937.

51 ibid; Mayua (n 41) 40.

52 VCLT (n 21).

${ }^{53}$ Von Bogdandy (n 26) 223.

${ }^{54}$ For example, the United Nations: G Gaja, 'The Protection of General Interests in the International Community' General Course of Public International Law (2011) 364 Recueil des Cours 9, 29; E De Wet, 'The Emergence of International and Regional Value Systems as a Manifestation of the International Constitutional Order’ (2006) 19 Leiden Journal of International Law 611, 611- 612.

55 Shelton (n 20) 194.

${ }^{56} \mathrm{~J}$ Vidmar, 'Norm Conflicts and Hierarchy in International Law' in De Wet and Vidmar (n 43) 13, 14.

${ }^{57}$ De Wet (n 54) 612.

58 Vidmar (n 56) 40.

${ }^{59}$ U Beyerlin, 'Different Types of Norms in International Environmental Law, Policies, Principles and Rules' in D Bodansky, J Brunnée and E Hey (eds), The Oxford Handbook of International Environmental Law (Oxford University Press 2008) 426, 426.

${ }^{60}$ Shelton (n 20) 295; PM Dupuy, Droit International Public (3rd edn, Dalloz 1995) 14.
} 
and academic writings as 'subsidiary sources of law'. ${ }^{61}$ By definition, 'subsidiary' means that judicial decisions and academic writings are additional and therefore possibly inferior to treaties, international custom and general principles of law.

Such reasoning is in line with the second consideration of a normative hierarchy in international law, which is the existence of soft law. ${ }^{62}$ Soft law consists of rules that are neither binding in nature nor completely lacking in legal significance. ${ }^{63}$ These include, for example, guidelines, action plans, resolutions, policy declarations and codes of conduct. The Rio Declaration on Environment and Development ${ }^{64}$ and Agenda $21^{65}$ are examples of soft law instruments in IEL. Since soft law is not legally binding, it is therefore inferior to legally binding norms such as MEAs, CIL and jus cogens norms.

Third, States may explicitly create norm hierarchies themselves by articulating such hierarchies in the instruments of international law. For example, Article 103 of the UN Charter ${ }^{66}$ provides that in the event of conflict between the obligations of its member States under the Charter and their obligations under any other international agreement, their obligations under the Charter will prevail. The UN Charter thus assumes priority over all and any other treaty arrangements between States in the case of conflict between these. The Rome Statute of the International Criminal Court ${ }^{67}$ (ICC Statute) also contains a somewhat similar provision where it sets out the hierarchy of norms to be applied in adjudication matters. ${ }^{68}$

A fourth consideration is the existence of peremptory norms that have emerged as a result of Article 53 VCLT. The International Law Commission (ILC) argues that jus cogens reflects a normative hierarchy in international law to the extent that these norms are based on the universally endorsed values of the international community. ${ }^{69}$ For example, the value placed on the protection of the fundamental right to life can be argued to have led to the recognition of the prohibition of torture and genocide as jus cogens norms. ${ }^{70}$ Illuminating the relationship between jus cogens norms and the normative hierarchy theory, the International Criminal Tribunal for the Former Yugoslavia (ICTY) in Prosecutor v Anto Furundzija ${ }^{71}$ stated that the prohibition of torture is a jus cogens norm because of the 'importance of the values that it protects'. By virtue of their being based on the value system of the international community, jus cogens norms are therefore hierarchically superior to all other international law norms. Moreover, jus cogens norms can also be argued to be hierarchically superior norms to the extent that they are non-derogable, could invalidate norms that are inconsistent with them, and could pre-determine the creation of other norms. To this end, jus cogens are supposedly situated at the highest level of the international law hierarchy, in very much the same way as human rights are often regarded as being situated at the top of the normative hierarchy in domestic constitutional legal orders. We return to this issue in greater detail below.

Despite the valid criticism that could be raised against the abstract nature of normative hierarchy and its practical utility in international law, there are several advantages to employing

\footnotetext{
${ }^{61}$ Statute of the International Court of Justice (adopted 26 June 1945, entered into force 24 October 1945) 33 UNTS 993 (ICJ Statute) art 38(1)(d).

62 Shelton (n 20) 319; Petsche (n 40) 22.

${ }^{63}$ See, e.g., A Guzman and T Meyer, 'International Soft Law' (2010) 2 Journal of Legal Analysis 171.

${ }^{64}$ Rio Declaration on Environment and Development in 'Report of the United Nations Conference on Environment and Development' UN Doc A/CONF.151/26 (vol I) (12 August 1992).

65 'Agenda 21: Programme of Action for Sustainable Development' UN Doc A/Conf.151/26 (14 June 1992).

${ }^{66}$ Charter of the United Nations (adopted 26 June 1945, entered into force 24 October 1945) 1 UNTS XVI.

${ }^{67}$ Rome Statute of the International Criminal Court (adopted 17 July 1998; entered into force 1 July 2002) 2187 UNTS 90.

68 ibid art 21.

${ }^{69}$ ILC (n 40) para 365.

${ }^{70}$ Questions Relating to the Obligation to Prosecute or Extradite (Belgium v Senegal) (Judgment) [2012] ICJ Rep 422 para 99; Armed Activities on the Territory of the Congo (DRC v Uganda) (Judgment) [2006] ICJ Rep 126.

${ }^{71}$ Prosecutor v Anto Furundzija, International Criminal Tribunal for the former Yugoslavia (ICTY) (1998) IT-9517/1-T para 153.
} 
the normative hierarchy approach in international law. The first is to resolve norm conflicts. A conflict of norms can be described as a situation whereby there are two conflicting norms and in obeying or applying one norm, the other norm is necessarily or possibly violated. ${ }^{72}$ A normative hierarchy could resolve such conflicts through determining which norm is superior to the other in terms of content and acceptance by the international community. As such, it can also be argued that a normative hierarchy makes adjudication easier in the face of norm conflicts, since a court does not need to determine how to construe one rule to conform to another because the apex norm will trump all others. ${ }^{73}$ This could ensure that international law is generally more certain, accessible and stable, a situation which has the effect of possibly preventing future norm conflicts and further developing international law generally. In the environmental context, it would thus be possible to afford a hierarchically superior environmental law norm, and the obligations it imposes, precedence if it conflicts with a hierarchically inferior norm that run counter to the environmental protection obligations that the former seeks to impose on States. Normative hierarchy is also important for the reasons of "mode control' 74 as it sets out what is lawful and unlawful, applicable rights and duties, and whether a State is in conformity or in violation of a norm. This could go a long way in clarifying specific environmental obligations of States in terms of binding higher order IEL. Further, a normative hierarchy could protect the fundamental values of the international community embodied as apex norms. By entrenching and elevating such values, a normative hierarchy has the effect of 'constitutionalizing' such norms, which will be binding on States despite their lack of consent. This could be particularly beneficial to force States to comply with at least some of their IEL obligations. We reflect immediately below on the potential of certain CIL and jus cogens norms as possible apex norms in IEL's normative hierarchy to fulfil such a function.

\section{CUSTOMARY INTERNATIONAL ENVIRONMENTAL LAW}

The purpose of this part is to explore some potential environmental CIL norms to determine whether they could form part of the upper echelons of IEL's normative hierarchy. As highlighted earlier, CIL is international law that is binding on the international community as a whole. CIL norms have been 'accepted by States beyond their treaty-law formulations' and they have binding authority 'over each and every State in the absence of any written legal commitment by them' ${ }^{75}$ To this end, CIL should ideally serve to complement MEA obligations rather than to replace them; a notion supported by the ICJ's acknowledgement in the Case Concerning North Sea Continental Shelf ${ }^{76}$ that under certain conditions, CIL norms may emerge that are identical to treaty obligations. The importance of CIL, and its potential advantages for environmental compliance and enforcement, are further evident when one considers that many MEAs remain unimplemented or only partially implemented; not all States that are concerned with a specific environmental matter that an MEA seeks to regulate is part of that particular MEA; and multiple interpretation and enforcement challenges are associated with several MEAs, even when they are fully implemented.$^{77}$ At least some of these regulatory deficiencies could be addressed by CIL.

One potential drawback of CIL, some might argue, is the persistent objector rule, in terms of which a State which consistently refuses the existence or applicability of a particular CIL rule

\footnotetext{
${ }^{72}$ H Kelsen, 'Derogation' in RA Newman (ed), Essays in Jurisprudence in Honor of Roscoe Pound (Bobbs-Merrill 1962) 339.

${ }^{73}$ FF Martin, 'Delineating a Hierarchical Outline of International Law Sources and Norms' (2002) 65 Saskatchewan Law Review (2002) 333, 335; Al-Adsani v United Kingdom, App No 35763/97 (ECtHR, 21 November 2001).

${ }^{74}$ Koskenniemi (n 20) 567.

75 PM Dupuy, 'Formation of Customary International Law and General Principle' in Bodansky et al (n 59) 450,452 and 454.

${ }^{76}$ Case Concerning North Sea Continental Shelf (Germany v Denmark; Germany v Netherlands) (Judgment) [1969] ICJ Rep 3. This position was later reiterated by the ICJ in Case Concerning Military and Paramilitary Activities in and against Nicaragua (Nicaragua v United States) (Judgment) [1986] ICJ Rep 93 paras 93-94.

${ }^{77}$ Dupuy (n 75) 450.
} 
will not be bound by that CIL rule. ${ }^{78}$ Yet, while the persistent objector rule may be seen to provide and easy way out for States that attempt to circumvent their binding customary obligations, its negative impact on the effectiveness of CIL and the legitimacy of this body of law should not be over-stressed. As Dupuy reminds us:

the actual practice of the 'persistent objector' is seldom sufficient to protect a dissenting State from the compulsory effect of some rules. This is especially the case when the rest of the international community is largely in agreement about the binding nature of the rule in question. In those cases, a State's behaviour rarely remains coherent and comprehensive enough in the long term to achieve the desired result - that is, of not being bound by the rule. ${ }^{79}$

And even where the persistent objector rule effectively enables a State not to be bound by a specific CIL rule, that fact alone would not significantly impact that rule's relatively elevated position in the normative hierarchy in IEL, mainly because of its universally binding status with respect to all other States which still remain subject to it.

Further reflecting on the elevated position of CIL in the normative hierarchy, there is a view that ' $[\mathrm{t}]$ reaties rank second [below CIL], since their binding nature rests on the customary rule of pacta sunt servanda'; ${ }^{80}$ although this view should probably be qualified in the sense that CIL are merely of more universal application than MEAs. Moreover, while the persistent objector rule might render some CIL norms normatively inferior to peremptory jus cogens norms (which States can never object to), CIL remains normatively superior to soft law by virtue of CIL's being universally binding without the need for a written law to be ratified.

A generally endorsed two-pronged test is applied to prove that a specific rule has attained CIL status. The first material part of this test requires that there must be State practice (usus) showing States' customary adherence to the rule. State practice is an objective requirement and political statements by States, or their mere declaration of the recognition of a rule, do not necessarily suffice for the purposes of State practice. ${ }^{81}$ State practice must rather be widespread and repetitive, ${ }^{82}$ although it can be argued that universal acceptance is not necessary. ${ }^{83}$ With reference to IEL, it is argued that if a particular environmental problem is uniformly regulated in a number of MEAs, this may be regarded as evidence of $u s u s .{ }^{84}$ The second requirement for a norm to attain CIL status is opinio juris (or the intellectual or physiological element), which refers to States' intention to be bound by the norm in question, or their conviction that uniform practice is mandatory. ${ }^{85}$ As such, opinio juris is a subjective requirement which is far more difficult to determine than usus (although opinio juris may be implied by usus), because it essentially requires evidence of a State's state of mind; or its conviction. ${ }^{86}$

There is still no general consensus on the norms which have CIL status in IEL. The following discussion will focus on four norms: the no-harm principle, sustainable development, the precautionary principle and the polluter pays principle. All four of these usually form the crux of most enquiries into the customary international environmental law debate.

\footnotetext{
${ }^{78}$ J Crawford, Brownlie's Principles of Public International Law (8th edn, Oxford University Press 2012) 11.

${ }^{79}$ Dupuy (n 75) 455.

${ }^{80}$ B Conforti and A Labella, An Introduction to International Law (Martinus Nijhoff 2012) 67.

${ }^{81}$ Case Concerning Military and Paramilitary Activities in and against Nicaragua (n 78) para 184.

${ }^{82}$ Fisheries Jurisdiction Case (United Kingdom v Iceland) (Judgment) [1974] ICJ Rep 3 paras 23-26.

${ }^{83}$ J Dugard, International Law: A South African Perspective (4th edn, Juta 2011) 27; Case Concerning North Sea Continental Shelf (n 76) para 229.

${ }^{84}$ U Beyerlin and T Marauhn, International Environmental Law (Hart 2011) 282.

${ }^{85}$ Conforti and Labella (n 80) 31.

${ }^{86}$ Thirlway, 'The Sources of International Law' in M Evans (ed), International Law (4th edn, Oxford University Press 2014) 91,99 .
} 


\subsection{No-harm principle}

The Permanent Court of International Justice in S.S. Wimbledon ${ }^{87}$ stressed that State sovereignty is not inalienable, meaning it can be limited. Such a viewpoint is exemplified by the no-harm principle, which first emerged in an environmental context in the Trail Smelter Arbitration, ${ }^{88}$ in which it was held that no State may use its territory in a way that causes harm to the territory of another State. Transboundary environmental harm usually takes three forms: air pollution, the transboundary movement of hazardous waste and the pollution of a transboundary environmental resource such as watercourses. ${ }^{89}$ It is probably correct to say that the no-harm principle does not absolutely prohibit all and any transboundary harm: it simply suggests an obligation on States to exercise due diligence in their relations with one another that could cause transboundary harm..$^{90}$

State practice and opinio juris for the no-harm principle are reflected by the principle's subsequent codification in a number of soft law instruments and MEAs and recognition by international courts. After its recognition in Trail Smelter, the no-harm principle was included in Principle 21 of the Stockholm Declaration, which specifies States have 'the sovereign right to exploit their own resources pursuant to their own environmental policies, and the responsibility to ensure that activities within their jurisdiction or control do not cause damage to the environment of other States or of areas beyond the limits of national jurisdiction'. The no-harm principle was also subsequently included as Principle 2 of the Rio Declaration. Although not binding, these soft law instruments reflect the opinion of the majority of States and the widespread acceptance of the no-harm principle. The no-harm principle is also recognized in a number of MEAs such as the United Nations Framework Convention on Climate Change (UNFCCC) and the Convention on Biological Diversity (CBD). ${ }^{91}$

The ICJ has endorsed the no-harm principle on a number of occasions. In the Corfu Channel case, ${ }^{92}$ for example, the Court held that a State may not knowingly allow its territory to be used to injure another State. Other judicial bodies such as the Arbitral Tribunal in the Lake Lanoux Arbitration ${ }^{93}$ stated that where a shared resource is concerned, a State must take the interests of other States into account before engaging in an activity which may cause harm to others. The no-harm principle has also been endorsed through the codification work of the ILC, ${ }^{94}$ and in declarations and resolutions adopted by the United Nations, ${ }^{95}$ and other international organizations such as the Organisation for Economic Co-operation and Development (OECD). ${ }^{96}$

\footnotetext{
${ }^{87}$ S.S Wimbledon (United Kingdom v Japan) (1923) PCIJ Rep Series A No 1.

${ }^{88}$ Trail Smelter Arbitration (United States v Canada) Arbitral Tribunal (1941) 3 RIAA 1905.

${ }^{89}$ A Schwabach, 'Transboundary Environmental Harm and State Responsibility: Customary International Law' in A Schwabach and AJ Cockfield (eds), International Law and Institutions (EOLSS Publishers Co Ltd 2009) 200.

${ }^{90}$ C Redgwell, 'International Environmental Law' in Evans (n 86) 688, 697.

${ }^{91}$ United Nations Framework Convention on Climate Change (adopted 29 May 1992, entered into force 21 March 1994) 1771 UNTS 107 (UNFCCC) art 194(2); Convention on Biological Diversity (adopted 5 June 1992, entered into force 29 December 1993) 1760 UNTS 79 (CBD) art 3. Other examples in this regard include the Convention on Long Range Transboundary Air Pollution (adopted 17 November 1979, entered into force 16 March 1983) 1302 UNTS 217 preamble; United Nations Convention on the Law of the Sea (adopted 10 December 1982, entered into force 16 November 1994) 1833 UNTS 3 art 194(2) and the Convention on the Transboundary Effects of Industrial Accidents (adopted 17 March 1992, entered into force 19 April 2000) 2105 UNTS 457 art 192(2).

${ }^{92}$ Corfu Channel Case (United Kingdom v Albania) (Judgment) [1949] ICJ Rep 4 para 22. See also Legality of the Threat or Use of Nuclear Weapons (Advisory Opinion) [1996] ICJ Rep 266 para 29; Case Concerning the GabčíkovoNagymaros Project (Hungary v Slovakia) (Judgment) [1997] ICJ Rep 7 (Gabčíkovo-Nagymaros).

${ }^{93}$ Lake Lanoux Arbitration (Spain v France) Arbitral Tribunal (1957) 12 RIAA 281.

${ }^{94}$ International Law Commission 'Draft Articles on Prevention of Transboundary Harm from Hazardous Activities' UN Doc A/56/10 (11 May 2001) art 3 (Draft Articles).

${ }^{95}$ For example, UNGA 'Resolution on the Cooperation in the Field of Environment Concerning Natural Resources Shared by Two or More States' UN Doc A/RES/3129(XXVIII) (13 December 1973); Beyerlin and Marauhn (n 84) 44.

96 OECD, 'Recommendation of the Council on Guiding Principles concerning International Economic Aspects of Environmental Policies'

$(26$ May 
Consequently, there seems to be general consensus that the no-harm principle has attained CIL status. $^{97}$

It is often argued that the duty to conduct a transboundary environmental impact assessment (EIA) under certain circumstances has also attained CIL status, notably to the extent that this duty is seen to be part of the no-harm principle. ${ }^{98}$ The duty to conduct a transboundary EIA involves an evaluation by a State of the likely impact of a proposed activity on the environment. ${ }^{99}$ This duty is enshrined, among others, in Principle 17 of the Rio Declaration, the United Nations Convention on the Law of the Sea, and the US-Canada Air Quality Agreement, ${ }^{100}$ and it surfaces in article 7 of the ILC's Draft Articles on the Prevention of Transboundary Harm. ${ }^{101}$ The ICJ has also indirectly confirmed the duty to conduct a transboundary EIA in some cases, ${ }^{102}$ and there seems to be sufficient support for including this aspect into the ambit of the no-harm principle.

\subsection{Sustainable development}

Sustainable development is generally taken to mean development that meets the needs of the present generation without compromising the ability of future generations to meet their own needs. ${ }^{103}$ It requires the balancing of environmental, social and economic interests during 'development', broadly conceived. Sustainable development is also concerned with inter- and intra-generational equity, which is the balancing of interests between members of this generation and between the present and future generations. It is argued that sustainable development is a universally accepted notion because of its proliferation in global politics and governance (as the adoption of the Sustainable Development Goals in 2015 by the United Nations General Assembly aptly suggests), ${ }^{104}$ and more specifically as a cornerstone and guiding principle of IEL. ${ }^{105}$

To demonstrate its increasing traction, sustainable development has been included as a notion and objective in several MEAs. The UNFCCC and the Kyoto Protocol, for example, provide that sustainable development is an important objective for combating climate change; ${ }^{106}$ and States 'have a right to, and should promote sustainable development'. ${ }^{107}$ The United Nations Convention to Combat Desertification refers, inter alia, to sustainable economic growth in its preamble as a priority of developing countries, whereas the CBD stresses the importance of 'sustainable use'. ${ }^{108}$ Moreover, the ICJ has referred to sustainable development in the Gabčikovo-Nagymaros case, ${ }^{109}$

\footnotetext{
$<$ http://acts.oecd.org/Instruments/ShowInstrumentView.aspx?InstrumentID=4\&Lang=en> ～(OECD Guiding Principles).

${ }^{97}$ See, among the extensive range of publication on this topic, J van Dyke, 'Liability and Compensation for Harm Caused by Nuclear Activities' (2006) 35 Denver Journal of International Law and Policy 13, 13-17.

${ }^{98}$ P Birnie, A Boyle and C Redgwell, International Law and the Environment (3rd edn, Oxford University Press 2009) 104.

${ }^{99}$ Convention on Environmental Impact Assessment in a Transboundary Context (adopted 25 February 1991, entered into force 10 September 1997) 1989 UNTS 309 (Espoo Convention) art 1(vi).

${ }^{100}$ Agreement on Air Quality (Canada-US) (adopted 13 March 1991, entered into force 13 March 1991), 1852 UNTS 79.

101 Draft Articles (n 94).

102 Gabčikovo-Nagymaros (n 92) para 41; Pulp Mills on the River Uruguay (Argentina v Uruguay) (Judgment) [2010] ICJ Rep 156 para 204.

103 World Commission on Environment and Development, Our Common Future (Oxford University Press 1987).

104 See generally D French and LJ Kotzé (eds) Global Goals: Law, Theory and Implementation (Edward Elgar 2018).

105 O McIntyre, 'The Role of Customary Rules and Principles of International Environmental Law in the Protection of Shared International Freshwater Resources' (2006) 46 Natural Resources Journal 157, 173.

${ }^{106}$ UNFCCC (n 91) art 2; Kyoto Protocol to the UNFCCC (adopted 11 December 1997, entered into force 16 February 2005) 2303 UNTS 148 (Kyoto Protocol) art 2(1).

${ }^{107}$ UNFCCC (n 91) art 3.

108 United Nations Convention to Combat Desertification (adopted 17 June 1994, entered into force 26 December 1996) 1954 UNTS 3 art) 1, 5, 8 and 10.

${ }^{109}$ Gabčikovo-Nagymaros (n 92) para 162.
} 
emphasizing the interconnectedness of economic development and the protection of the environment, although it stopped well short of pronouncing on the normative status of the concept.

Despite such widespread recognition, it remains unclear whether sustainable development is part of soft law, a mere political objective, or whether it has since become a universally binding global legal standard to measure conduct that may impact on the environment. ${ }^{110}$ Proliferation of references to sustainable development has arguably only led to confusion rather than clarity of the concept, especially because of its being frequently invoked by States in global law, politics and governance as a palliative to mean at once everything and nothing at all. ${ }^{111}$ The general view accordingly seems to be that sustainable development has not attained CIL status. ${ }^{112}$ Despite its proliferation, there is little evidence suggesting that there is a widespread and consistent State practice promoting sustainable development, while there is even less evidence of opinio juris. That we are probably entering the Anthropocene, especially as explicated by the continuing deterioration of Earth system integrity, is arguably persuasive evidence that States have altogether failed to implement sustainable development consistently in any widespread manner, while intending to be bound by its lofty ideals. It is perhaps more accurate to say that sustainable development remains a political goal to be reached somewhere in future rather than a norm to which present practice must adhere. Moreover, since sustainable development is ambiguous and susceptible to various interpretations, it can be argued that it is unfit, for now at least, to be a higher-order legal norm which can 'deploy any appreciable steering effect on States' environmental behaviour'. ${ }^{113}$ As such, sustainable development can best be described as a nonbinding principle 'that guides States in their decision-making', ${ }^{114}$ and at worst as an ideological palliative that is politically loaded, but normatively rather empty. ${ }^{115}$

\subsection{Precautionary principle}

Principle 15 of the Rio Declaration provides for the precautionary principle, which states that the lack of scientific certainty regarding an identified environmental risk must not be a reason to postpone action that could prevent environmental harm. ${ }^{116}$ It is essentially a principle for inducing States to foresee and avoid or minimize environmental risks. The precautionary principle also could help in identifying the general standards for due diligence and the appropriate standard of care required for preventing transboundary harm. ${ }^{117}$ To this end, it has been argued that the precautionary principle is possibly related to the duty to conduct a transboundary EIA, ${ }^{118}$ as described earlier, although this does not necessarily mean that the precautionary principle is also a CIL norm as a result.

The precautionary principle has been included in a number of MEAs. For example, the Vienna Convention for the Protection of the Ozone Layer and the Montreal Protocol refer to the precautionary principle in their preambles. ${ }^{119}$ The CBD provides in its preamble that where there is a threat of loss of biological diversity, the lack of scientific certainty should not be a reason to postpone action aimed at avoiding or minimizing such loss. The precautionary principle is also

\footnotetext{
${ }^{110}$ Beyerlin and Marauhn (n 84) 80-81.

111 ibid 76.

112 De Wet (n 26) 62.

113 Beyerlin and Marauhn (n 84) 81.

114 ibid.

115 B Richardson, ‘A Damp Squib: Environmental Law from a Human Evolutionary Perspective’ (2011) 7 Osgoode Hall Law School Comparative in Law and Political Economy Research Paper Series 1, 31.

${ }^{116}$ Beyerlin and Marauhn (n 84) 50.

${ }^{117}$ McIntyre (n 105), 172.

${ }^{118}$ Birnie et al (n 98) 120.

${ }^{119}$ Vienna Convention for the Protection of the Ozone Layer (adopted 22 March 1985, entered into force 22 September 1988) 1513 UNTS 293 preamble; Montreal Protocol on Substances that Deplete the Ozone Layer (adopted 16 September 1987, entered into force 1 January 1989) 1522 UNTS 3 (preamble.
} 
provided in Article 1 of the Cartagena Biosafety Protocol, ${ }^{120}$ the United Nations Economic Commission for Europe Watercourses Convention, ${ }^{121}$ and as a guiding principle in Article 3(3) of the UNFCCC. Two of the dissenting judges in the Nuclear Tests case referred to the precautionary principle as an emerging feature of IEL. ${ }^{122}$ In the Southern Bluefin Tuna case ${ }^{123}$ the International Tribunal for the Law of the Sea believed that lack of scientific certainty should not be used to delay the conservation of the stock of southern Bluefin tuna. The Tribunal did, however, not clarify if the precautionary principle could be considered binding CIL.

It is unlikely at this stage that the precautionary principle could be seen to have achieved CIL status, and the predominant view is that it is at best an 'emerging rule of customary international environmental law'. ${ }^{124}$ Much like sustainable development discussed above, there is no clear evidence that the precautionary principle is a command to act which imposes duties on States to take definable action. ${ }^{125}$ Furthermore, international courts have been reluctant to apply the principle 'as a legal yardstick for solving interstate disputes'. ${ }^{126}$

\subsection{Polluter pays principle}

In basic terms, the polluter pays principle means that the party responsible for polluting the environment must bear the costs of remediating such pollution and/or the costs of preventing and controlling such pollution. To this end, the principle aims to regulate pollution, ensure environmentally sustainable activities, ${ }^{127}$ and provide for the "most efficient way to allocate costs of pollution prevention and control measures'. ${ }^{128}$ The polluter pays principle was first identified in the OECD's Guiding Principles ${ }^{129}$ as a method to be used for the allocation of the cost of pollution prevention and control, before its inclusion as Principle 16 in the Rio Declaration.

The polluter pays principle is further recognized in a number of MEAs, ${ }^{130}$ although its application in these instruments varies. In some contexts, such as the Barcelona Convention for the Protection of the Mediterranean Sea against Pollution, ${ }^{131}$ the principle is 'represented as cost bearing for pollution control, prevention and reduction measures', which measures are set by national authorities or within MEAs. ${ }^{132}$ In other treaties, States are urged to be 'guided' by the principle and in yet others 'to take the principle into account' or to 'apply' it. ${ }^{133}$ In some contexts,

\footnotetext{
${ }^{120}$ Cartagena Protocol on Biosafety to the Convention on Biological Diversity (adopted 29 January 2000, entered into force 11 September 2003) 2226 UNTS 208.

${ }^{121}$ Convention on the Protection and Use of Transboundary Watercourses and International Lakes (adopted 17 March 1992, entered into force 6 October 1996) 1936 UNTS 269 (Helsinki Convention) art 2(5)(a).

${ }^{122}$ Nuclear Tests (New Zealand v France) (Judgment) [1974] ICJ Rep 253 paras 412 (Dissenting Opinion) and 342 (Dissenting Opinion).

${ }^{123}$ Southern Bluefin Tuna Case (Australia v Japan; New Zealand v Japan) ITLOS Case No 3 (Order of 27 August 1999) para 79.

124 Beyerlin and Marauhn (n 84) 283.

125 ibid 50 .

126 ibid 52.

127 P Schwartz, 'The Polluter-Pays Principle' in M Fitzmaurice, DM Ong and P Merkouris (eds), Research Handbook on International Environmental Law (Edward Elgar 2010) 243, 244.

${ }^{128}$ D Anton and D Shelton Environmental Protection and Human Rights (Cambridge University Press 2011$) 86$.

129 OECD Guiding Principles (n 96).

${ }^{130}$ For example, the Convention for the Protection of the Marine Environment of the North-East Atlantic (adopted 22 September 1992, entered into force 25 March 1998) 2354 UNTS 67 and the Stockholm Convention on Persistent Organic Pollutants (adopted 22 May 2001, entered into force 17 May 2004) 2256 UNTS 119.

${ }^{131}$ Convention for the Protection of the Mediterranean Sea against Pollution (adopted 16 February 1976, entered into force 12 February 1978) (as amended in 1995) 1102 UNTS 27.

132 Schwartz (n 127).

${ }^{133}$ For example, the Convention on Co-operation for the Protection and Sustainable Use of the Danube River (adopted 29 June 1994, entered into force 22 October 1998) 21997A1212 (03) (31997D0825) art 4(4); Helsinki Convention (n 121) art 2(5)(b).
} 
the polluter-pays principle is also recognized as a general principle of IEL, ${ }^{134}$ and in other contexts as an indication of the acceptance of responsibility for pollution. ${ }^{135}$ Despite such wide recognition, the international judiciary has not yet pronounced on the normative qualities of the principle. Furthermore, the softened wording in Principle 16 of the Rio Declaration ('should endeavour to promote') might show that the principle lacks the binding effect of a legal rule. ${ }^{136}$ There accordingly seems to be general agreement that the polluter-pays principle has not achieved CIL status yet, although it is recognized as legal rule, mostly in the European regional context. ${ }^{137}$

The foregoing discussion illustrates that by their very universally binding nature, CIL norms are situated higher up in IEL's normative hierarchy. While this is potentially advantageous insofar as such universally binding norms could compensate for regulatory deficiencies resulting especially from MEAs, there is only one environmental norm that has to date been accepted as having customary international law status, i.e. the no-harm rule and its associated obligation to conduct a transboundary EIA.

\section{ENVIRONMENTAL JUS COGENS NORMS}

At its most basic, jus cogens is understood as universally imperative, compelling and obligatory law (or jus strictum) that sharply contrasts with jus dispositivum (voluntary law which yields to the will of the parties). ${ }^{138}$ Jus cogens norms are compelling to the extent that they are mandatory, do not permit derogation, and can be modified only by general international norms of equivalent authority (i.e. other jus cogens norms). ${ }^{139}$ They are universal in that they are seen to have erga omnes effect, meaning that they apply to all members of the international community of States, even if a State does not consent to a jus cogens rule's mandatory application. ${ }^{140}$ An obligation erga omnes also gives the rest of the international community an interest in its enforcement, and they are obligatory to the extent that they create negative obligations on States to refrain from doing something. ${ }^{141}$ Collectively, these characteristics confirm that there is something inherently constitutional about jus cogens norms to the extent that they are considered apex universally binding norms of a normative hierarchy in international law. ${ }^{142}$

Even though jus cogens norms owe their existence to the VCLT, this treaty does not contain any criteria to apply in an effort to determine the existence of specific jus cogens norms. Given the lack of guidance in the relevant treaty provisions, the identification and elaboration of specific jus cogens norms have been left to States, courts, bodies such as the ILC, and the academe. Although there is no universal agreement on this, the rules of international law that are currently accepted as having jus cogens status include, among others: the prohibition of the threat or use of force against

\footnotetext{
${ }^{134}$ For example, the Convention on the Transboundary Effects of Industrial Accidents (n 93) preamble; International Convention on Oil Pollution Preparedness, Response and Cooperation (adopted 30 November 1990, entered into force 13 May 1995) 1891 UNTS 51.

${ }^{135}$ For example Kyoto Protocol (n 106); Bamako Convention on the Ban of the Import into Africa and the Control of Transboundary Movement and Management of Hazardous Wastes within Africa (adopted 30 January 1991, entered into force 22 April 1998) 2101 UNTS 242; Basel Convention on the Control of Transboundary Movements of Hazardous Wastes and Their Disposal (adopted 22 March 1989, entered into force 5 May 1992) 1673 UNTS 57.

${ }^{136}$ Beyerlin (n 59).

${ }^{137}$ P Sands and J Peel Principles of International Environmental Law (3rd edn, Cambridge University Press 2012) 280.

${ }^{138}$ Dissenting Opinion of Judge Tanaka in South West Africa Cases (Ethiopia v South Africa; Liberia v South Africa) Second Phase (Judgment) [1966] ICJ Rep 298.

${ }^{139}$ EJ Criddle and EF Decent, 'A Fiduciary Theory of Jus Cogens' (2009) 34 Yale Journal of International Law 331, 332.

${ }^{140}$ A point that was confirmed by the ICJ in Barcelona Traction (n 46). See also De Wet (n 26) 61. The author, however, at the same time points out that not all erga omnes obligations necessarily have jus cogens status.

${ }^{141}$ Jus cogens norms do not create positive obligations that compel States to do something, for example, to make good human rights abuses. They only compel States not to embark on human rights abuses. This is often seen as one of the greatest drawbacks of jus cogens rules; Vidmar (n 56) 33.

${ }^{142}$ See generally De Wet and Vidmar (n 43).
} 
the territorial integrity or political independence of any State; the prohibition of genocide; the prohibition of torture; crimes against humanity; the prohibition of slavery and slave trade; the prohibition of piracy; the prohibition of racial discrimination and apartheid; and the prohibition of hostilities or force directed at a civilian population. ${ }^{143}$ Most of the recognized jus cogens norms to date are human rights-type norms, ${ }^{144}$ although Article 64 of the VCLT envisages the creation of new peremptory norms of general international law, which, for present purposes might include environmental jus cogens norms.

Based as they are on notions of human rights, jus cogens norms are value-laden and have a strong ethical underpinning. ${ }^{145}$ Arguably, the protection of the values of the international community is both the purpose and 'paramount criterion for jus cogens norms. ${ }^{146}$ In Prosecutor $v$ Anto Furundzija, ${ }^{147}$ the ICTY stated that the prohibition of torture is a jus cogens norm because of the 'importance of the values that it protects'. The ICJ in Barcelona Traction ${ }^{148}$ also held that prohibitions on genocide, slavery and racial discrimination should be conferred with peremptory erga omnes status because of the 'importance of the rights involved'. The ILC in the work of the Study Group on the Fragmentation of International Law ${ }^{149}$ stated that jus cogens norms become hierarchically superior because of the importance of their content as well as the universal acceptance of their superiority. As such, the threshold for identifying jus cogens norms is arguably high. ${ }^{150}$

Jus cogens norms are subject to so called 'double acceptance' by the international community of States. ${ }^{151}$ Although there is no formal link between jus cogens and CIL norms, States in principle usually first agree to the CIL status of the norm, i.e. usus and opinio juris must be proved. The second stage will require States to agree on the non-derogability of the norm in question. ${ }^{152}$ In justifying their finding that the prohibition of torture is a jus cogens norm, the ICJ in Belgium v Senegal said that the norm in question has 'widespread international practice and is based on the opinio juris of States'. ${ }^{153}$ The acceptance of the peremptory character of a norm is evidenced by considering the values that such a norm protects and whether the norm has a strong ethical underpinning. ${ }^{154}$ In this view jus cogens norms essentially appear as elevated and distinct CIL norms.

Jus cogens norms are absolute in character, and the non-derogability criterion is both a prerequisite and consequence of jus cogens norms. ${ }^{155}$ This means that States cannot violate any jus cogens norm under any circumstances through, among others, treaties, unilateral acts or domestic laws. ${ }^{156}$ The non-derogability of jus cogens norms means that they are binding even on States that have objected to the norms. ${ }^{157}$ To this end, the ICJ has referred to jus cogens norms as 'intransgressible principles of international customary law'. ${ }^{158}$ In Prosecutor v Anto Furundzija, ${ }^{159}$

\footnotetext{
${ }^{143}$ E De Wet, 'Jus Cogens and Obligations Erga Omnes' in D Shelton (ed) The Oxford Handbook on International Human Rights Law (Oxford University Press 2013) 541, 543.

${ }^{144}$ For example, the prohibition of torture, aggression and slavery; De Wet and Vidmar (n 43 ) 3.

145 Vidmar (n 56).

146 EM Kornicker Uhlmann, 'State Community Interests, Jus Cogens and Protection of the Global Environment: Developing Criteria for Peremptory Norms' (1999) 11 Georgetown International Environmental Law Review 101, 108.

${ }^{147}$ Prosecutor v Anto Furundzija (n 71).

148 Barcelona Traction (n 46) para 33.

149 ILC (n 40).

${ }^{150}$ De Wet (n 143).

151 Vidmar (n 56).

152 ibid.

153 Questions Relating to the Obligation to Prosecute or Extradite case (n 70).

${ }^{154}$ Vidmar (n 56); De Wet (n 26) 57.

${ }^{155}$ Kornicker Uhlmann (n 146) 110.

${ }^{156}$ C Mik, 'Jus Cogens in Contemporary International Law' (2013) 23 Polish Yearbook of International Law 27, 44.

${ }^{157}$ Kornicker Uhlmann (n 146) 112.

${ }^{158}$ Legality of the Threat or Use of Nuclear Weapons (n 92) para 79.

${ }^{159}$ Prosecutor v Anto Furundzija (n 71) para 144.
} 
the ICTY held that the jus cogens norm on the prohibition of torture can never be derogated from, even in times of emergency. Relatedly, very much like domestic constitutional provisions and norms, jus cogens are onerous to amend or to modify. The modification of a jus cogens norm refers to its development, expansion in scope, replacement or abolition. ${ }^{160}$ It can be argued that since jus cogens norms protect the universally shared values of the international community, they cannot be easily modified for the purposes of durability and to avoid abuse of power. Therefore, the modification of a jus cogens norm arguably also requires that the modification be accepted by the international community of States as a whole, ${ }^{161}$ which of course creates a very high threshold.

Although there is extensive literature dealing with various general aspects of jus cogens, ${ }^{162}$ it has not been the subject of any sustained and thoroughgoing scholarly analysis in the environmental domain. ${ }^{163}$ The most common view is that environmental jus cogens norms do not exist, at least not yet. According to Birnie, Boyle and Redgwell:

What cannot be supposed is that environmental rules have any inherent priority over others save in the exceptional case of ius cogens norms .... No such norms of international environmental law have yet been convincingly identified, nor is there an obvious case for treating them in this way. ${ }^{164}$

Singleton-Cambage agreeing with this, explains that:

Currently, environmental rights and responsibilities are not recognized as having this legal status [of jus cogens], despite the fact that global environmental preservation represents an essential interest of all individuals within the entire international society. Sufficient time has not yet passed to enable environmental issues to evolve to this status of international law. The establishment of peremptory norms must develop from a specific practice for an extended period of time by the general majority of States. ${ }^{165}$

While conflict does arise in the environmental law and governance domain as a result of the inherently opposing goals of socio-economic development on the one hand and the concomitant need for environmental protection on the other (aptly expressed by the principle of sustainable development), such conflicts 'have not led international courts to employ the concept of ius cogens or to give human rights, environmental protection or economic development automatic priority'. ${ }^{166}$ Indeed, to date, no MEA has been declared ab initio invalid as a result of its or one of its provisions conflicting with a generally accepted jus cogens norm as per Articles 53 and 64 VCLT. Neither has a treaty nor one of its provisions been declared invalid because it contradicted a jus cogens norm on environmental grounds.

It is therefore unclear which IEL norms could be considered to have peremptory status. Based on the broader contextual discussion above, the following part investigates two IEL norms that could possibly already be or become jus cogens norms. These norms are the no-harm principle and the human right to a healthy environment which seem as the two most likely contenders for such a position, for reasons we set out below.

\footnotetext{
${ }^{160}$ A Orakhelashvili, Peremptory Norms in International Law (Oxford University Press 2009) 127.

161 T United Nations Office at Geneva, 'Criteria for Identifying Jus Cogens Norms in Public International Law' (Working Group 1-Final Report, International Law Seminar 51st Session, Geneva 2005).

${ }^{162}$ For example, Shelton (n 20); Rafferty (n 15); De Wet and Vidmar (n 43); P Weil, 'Towards Relative Normativity in International Law' (1983) 77 American Journal of International Law 413.

${ }^{163}$ LJ Kotzé, 'Constitutional Conversations in the Anthropocene: in Search of Environmental Jus Cogens Norms' (2015) 46 Netherlands Yearbook of International Law 241.

${ }^{164}$ Birnie et al (n 98) 109-110.

165 K Singleton-Cambage, 'International Legal Sources and Global Environmental Crises: The Inadequacy of Principles, Treaties and Custom' (1995) 2 ILSA Journal of International and Comparative Law 171, 185.

${ }^{166}$ Birnie et al (n 98) 115.
} 


\subsection{No-harm principle}

De Wet suggests that Articles 53 and 64 VCLT provide States sufficient freedom to determine themselves what are peremptory norms and what are not. ${ }^{167}$ As was explained above, in practice this would occur through a process that first identifies a norm as CIL and then an agreement on whether derogation is permitted from that customary norm or not. An appropriate place therefore to start searching for environmental jus cogens norms is in the sphere of already accepted CIL environmental norms. We have indicated above that the no-harm principle (and the concomitant duty to conduct a transboundary EIA) is arguably the only principle with customary law status in IEL. Today the no-harm principle 'has been so widely accepted in international treaty practice, numerous declarations of international organizations, the codification work of the ILC, and in the jurisprudence of the ICJ that it can be considered to be a customary substantive rule at the universal level'. ${ }^{168}$ It should thus easily satisfy the first stage of acceptance.

Whether it has attained the status of a norm from which no derogation is permitted (the second stage of acceptance) is, however, debatable. It is still unlikely that States have universally accepted any 'strong ethical [ecological] underpinning' 169 that should be associated with the noharm principle. Yet, because of its customary status and that it imposes negative obligations, suggest that at least theoretically, it has the potential to become a peremptory norm in future. Moreover, considered in the light of the Anthropocene and fast approaching planetary boundaries, and their implicit ethical implications to desist from causing irreversible socio-ecological harm, there is increasing motivation auguring support for universal recognition of the no-harm rule's potential peremptory character with a view to exercising greater global socio-ecological care by States. ${ }^{170}$

\subsection{The human right to a healthy environment}

Broadening jus cogens norms into the environmental domain can also be accomplished through human rights, especially if one agrees with the broader contention that existing jus cogens norms have a strong human rights underpinning, as most do. To date, there is neither a globally recognized international right to a healthy environment, nor an international human rights treaty which provides for an enforceable substantive right to a healthy environment. ${ }^{171}$ The majority of domestic constitutions, however, now recognize the right to a healthy environment in one form or another, while regionally the right is also entrenched in various human rights instruments. ${ }^{172}$ Yet, despite such widespread recognition, there is little evidence suggesting that the right to a healthy environment has already achieved the status of CIL. There is accordingly little chance of the right to a healthy environment attaining jus cogens status by evolving from an established CIL basis through the method of double acceptance discussed above.

\footnotetext{
167 De Wet (n 143) 542.

168 Beyerlin and Marauhn (n 84) 44.

169 Vidmar (n 56) 26.

${ }^{170}$ See, for example, Kim and Bosselmann who forcefully argue for the recognition and global adoption of 'ecological integrity' as a global environmental ethic for the Anthropocene. R Kim and K Bosselmann, 'International Environmental Law in the Anthropocene: Towards a Purposive System of Multilateral Environmental Agreements' (2013) 2 Transnational Environmental Law 285.

${ }^{171}$ See, e.g., JH Knox and R Pejan (eds), The Human Right to a Healthy Environment (Cambridge University Press 2018).

${ }^{172}$ For example, the African Charter on Human and Peoples' Rights (adopted 27 June 1981, entered into force 21 October 1986) 21 ILM 58 art 24; Arab Charter on Human Rights (adopted 23 May 2004, entered into force 15 March 2008) <http:/www.humanrights.se/wp-content/uploads/2012/01/Arab-Charter-on-Human-Rights.pdf $>$ art 26.1 and 38; and the Association of Southeast Asian Nations (ASEAN) Human Rights Declaration (adopted 18 November 2012) <http://www.asean.org/storage/images/ASEAN_RTK_2014/6_AHRD_Booklet.pdf $>$ art 25(2) and 28(f).
} 
It is, however, more likely that environment-related human rights interests could be protected through and by means of other human rights-based jus cogens norms. To the extent that human rights concerns in the environmental domain significantly overlap with other human rights issues, as is generally the case, it could be possible to argue that the remit of 'traditional' jus cogens norms related to, for example, the prohibition against apartheid (which per implication includes human rights issues such as the right to life, dignity and equality) should be expanded to include environmental considerations as well. After all, a degraded environment adversely impacts human dignity and the quality of life of people as the South African example of apartheid shows by means of which black South Africans have been relocated to live in so-called townships situated close to industries without any meaningful provision of water, waste and sanitation services. In his Separate Opinion in the Gabčikovo-Nagymaros judgment, Judge Weeramantry emphasized that the protection of the environment is important for the enjoyment of other human rights. ${ }^{173}$ For example, the right to life, which is considered to be a jus cogens norm, ${ }^{174}$ is enshrined in virtually every human rights convention, ${ }^{175}$ including, among others, in the European Convention on Human Rights and the American Convention on Human Rights, ${ }^{176}$ and it is a non-derogable right even in times of emergency. ${ }^{177}$ It could be argued that the destruction of life-sustaining environmental conditions directly and/or indirectly could violate the right to life. ${ }^{178}$ Through such a construction it would be possible to extend the peremptory obligation of the rights to life to encapsulate environmental protection, notably to the extent that such environmental protection is crucially necessary for the protection of life and preservation of human dignity.

On the foregoing account, we must conclude that currently, no explicit environmental jus cogens norms exist. There is, however, some scope for such rules to develop over time through existing CIL and through the global human rights agenda. The development of environmental jus cogens norms should, in our view, be a priority since their absence potentially mutes the prospects of creating a solid set of apex peremptory global environmental constitutional norms at the top of IEL's normative hierarchy that aim to secure more effective environmental care in the Anthropocene.

\section{CONCLUSION}

In this article, we investigated whether constitutional IEL norms exist thought the lens of global (environmental) constitutionalism and the theory of normative hierarchy. We situated the discussion against the backdrop of the Anthropocene trope with a view to highlighting the urgency of the debate and to emphasizing the need to create constitutional IEL norms that could contribute to addressing the ever-deepening socio-ecological crisis explicated by the Anthropocene. We first explained what is meant by the concepts of global constitutionalism, global environmental constitutionalism and normative hierarchy in international law, including a reflection on their relationship. We then sought to identify higher-order constitutional IEL norms by focusing specifically on CIL and jus cogens norms.

Our central hypothesis has been that the Anthropocene and its associated imagery of planetary boundaries require far more drastic universal (and preferably non-derogable) norms that bind States to their environmental protection obligations flowing from these norms, regardless of

\footnotetext{
173 Gabčikovo-Nagymaros (n 92) paras 91-92.

${ }^{174}$ Kornicker Uhlmann (n 146) 132.

175 ibid 128.

${ }^{176}$ European Convention for the Protection of Human Rights and Fundamental Freedoms (adopted 4 November 1950 , entered into force 3 September 1953) 213 UNTS 222 art 15; American Convention on Human Rights (adopted 22 November 1969, entered into force 18 July 1978) 1144 UNTS 123 art 27.

177 International Covenant on Civil and Political Rights (adopted 16 December 1966, entered into force 23 March 1976) 999 UNTS 171 art 4(2).

${ }^{178}$ L Berat, 'Defending the Right to a Healthy Environment: Toward a Crime of Geocide in International Law' (1993)

11 Boston University International Law Journal 327.
} 
whether they have agreed to these norms and their associated obligations. Looking for such norms that are situated at the top of IEL's hierarchy could potentially address some of the shortcomings and regulatory gaps of IEL, especially if one agrees with the view that 'the very structure of the international legal order is found to be wanting and consequently alternatives, however inchoate, must be considered'. 179

The 'alternatives' that the Anthropocene requires is a 'fundamental reorientation and restructuring of national and international [law and governance] institutions toward more effective Earth system governance and planetary stewardship' ${ }^{180}$ Plainly, our legal institutions must play a crucial role in changing the type and severity of human impacts that are leading to the present and predicted future encroachments on Earth system integrity. This must entail a dramatic rethink of IEL's composition, purpose and scope; which, perhaps inevitably, will have to occur also within the context of constitutionalism as we have argued above. Thus, if CIL and jus cogens are accepted to constitute some form of minimum global constitutional threshold of an international value system to which the international community of States is subjected to, ${ }^{181}$ then this international value system will have to be expanded to include notions of environmental care that are situated at the constitutional apex of IEL's normative hierarchy, if we were to contribute juridically to countering Anthropocene exigencies.

Our analysis suggests that the status quo with respect to those apex constitutional norms situated at the top of IEL's normative hierarchy is a mixed bag. Very few such norms currently exist. The no-harm principle, which includes the duty to conduct a transboundary EIA, is to date the only generally accepted customary environmental law norm. While the precautionary principle, the polluter-pays principle and the principle of sustainable development are arguably not CIL norms yet, they have the potential to become CIL over time which could significantly contribute to enhancing the superior normative force of some of IEL's norms. For this to happen, we would need to see a far more deliberate effort by States that clearly demonstrates their intention to be bound by these norms, including their intention to act within the normative boundaries set out by the environmental obligations imposed by the norms.

We also demonstrated that no explicit environmental jus cogens norms exist to date. The only potential for the development of an environmental jus cogens norm would be if States were to eventually recognize the peremptory nature of the no-harm principle, which, considering the slow development of customary environmental law norms, is unlikely to occur anytime soon. Until that happens, it is more likely that the normative force of peremptory norms could be extended into the environmental domain through human rights constructions, and specifically by addressing environmental protection through those environmentally incidental human rights norms that are currently recognized as having jus cogens status. While it would be far more preferable if explicitly clear environmental jus cogens norms were to be created, we believe using incidental human rights norms for environmental protection holds considerable potential in the short term. States, global judicial institutions such as the ICJ, and global civil society, if they do take their socio-ecological obligations seriously in the Anthropocene, must embark as soon as possible on utilizing this possibility.

Louis J. Kotzé is Research Professor of Law at North-West University, South Africa. He is currently a European Union Marie Sklodowska-Curie Research Fellow at the University of

\footnotetext{
${ }^{179}$ D French, 'Common Concern, Common Heritage and other Global(-ising) Concepts: Rhetorical Devices, Legal Principles or a Fundamental Challenge?' in M Bowman, P Davies and E Goodwin, Research Handbook on Biodiversity and Law (Edward Elgar 2016) 334, 335.

${ }^{180}$ F Biermann et al, 'Navigating the Anthropocene: Improving Earth Systems Governance' (2012) 335 Science 1306 , 1306; and more generally N Kanie et al, 'A Charter Moment: Restructuring Governance for Sustainability' (2012) 32 Public Administration and Development 292.

${ }^{181}$ Vidmar (n 56) 38.
} 
Lincoln, United Kingdom, where he leads a project titled 'Global Ecological Custodianship: Innovative International Environmental Law for the Anthropocene' (GLEC-LAW). Research for this article was supported by this project under grant agreement No. 751782, and was completed in April 2018.

Wendy Muzangaza is a fulltime doctoral candidate at the Faculty of Law, North-West University, South Africa. Parts of this research are based on her LLM dissertation titled: 'Normative Hierarchy in International Environmental Law - A Constitutional Reading', which she successfully defended at the North-West University in 2016. 